\title{
The Procedural Due Process Approach to Administrative Discretion: The Courts' Inverted Analysis
}

\author{
Tim Searchinger
}

Government agencies make countless decisions each year whether to grant or revoke benefits, adjudicating interests as varied as business licenses, parole release dates, and welfare payments. The Supreme Court's recognition in $1970^{1}$ of a duty to review the process by which agencies make these decisions has contributed to a due process "explosion."2 Unwilling to impose the full burden of this review either on themselves or on government agencies, ${ }^{3}$ the courts now self-consciously apply a two-part test: Before they ask what process is due to assure that decisions are minimally rational, ${ }^{4}$ courts first ask if a decision requires due process review at all.

In answering these questions, the courts have placed great importance on the extent to which the discretion of a decisionmaker is limited by rules

1. See Goldberg v. Kelly, 397 U.S. 254 (1970) (agency must follow due process before stopping welfare payments).

2. See J. Mashaw, Due Process in the Administrative State 9 \& nn.22-23 (1985) ("federal court complaints of procedural due process deprivation in the 1970's showed a 350 percent increase over the 1960's"). Among the benefits that have been the subject of due process challenges are: government contracts, welfare benefits, zoning rights, business and professional licenses, driver's licenses, public employment, student admissions and attendance at all levels of schooling, foster parenthood, lawyers' permission to appear pro hac vice, and a full range of prison interests including parole, pardon, discpline, transfer, and work-release. See also Rendleman, The New Due Process: Rights and Remedies, $63 \mathrm{Ky}$. L.J. 531, 532-34 (1975) (citing early post-Goldberg cases).

3. Because procedural due process applies only to the adjudicative process, the burden of review does not extend to decisions which courts characterize as legislative and not adjudicative. See NonMetallic Investment Co. v. State Bd. of Equalization of Col., 239 U.S. 441 (1915). Though a conventional distinction of administrative law, the line between adjudication and rulemaking is not always clear. See 2 K. Davis, Administrative Law TrEatise § 7:2 (1979); see also Elrod, The Effect of Procedural Due Process on State and Local Governmental Decisionmaking: Beyond Roth and Eastlake, 31 DEPAUL L. REv. 679, 706 \& n.204, 710 \& nn.237-38 (1982) (providing many examples in which distinction is wholly formalistic). In general, the theory is that rulemaking creates policies of general scope prospectively while adjudication applies policies to specific facts retrospectively. See United States v. Florida East Coast R. Co., 410 U.S. 224, 245 (1973). In this sense, virtually all government officials dealing directly with the public "adjudicate," so the potential reach of due process is enormous.

4. In its broadest formulations of the purposes of procedural due process, the Supreme Court usually refers to the assurance of rational decision-making. See, e.g., Wolff v. McDonnell, 418 U.S. 539,557 (1974) (procedural due process entitles prisoner "to those minimum procedures appropriate under the circumstances and required by the Due Process Clause to insure that the state-created right is not arbitrarily abrogated"). 
or standards. In general, if officials exercise broad discretion ${ }^{\mathbb{b}}$ to provide or revoke an interest, courts refuse to examine the procedures they follow. Further, if rules only partially confine discretion, some court decisions have cited the remaining discretion as a justification for reduced procedural protection.

This essay criticizes this approach as inverted. Although broad adjudicative discretion often has merit, it also poses a threat of unequal, capricious, even vindictive decisions. Instead of viewing unlimited discretion as a reason to limit judicial review, courts should treat the breadth of discretion as a "process" variable which they can influence and for which they can order compensating procedural checks.

\section{The Entitlement Analysis}

Before 1970 , courts did not generally apply procedural due process analysis to decisions affecting government benefits-interests that the individual would not enjoy except for a government grant. The courts reasoned that those decisions cannot deprive an individual of "life, liberty or property."' In the early 1970's, however, the Supreme Court reversed this stance and indicated in some decisions a willingness to provide due process protection to all important individual interests affected by government decisions. ${ }^{7}$

5. In a seminal article, Professor Ronald Dworkin has argued that the concept of adjudicative discretion has several different meanings. Dworkin, The Model of Rules, 35 U. CHI. L. REV. 14, 32-34 (1967). An administrator applying vague standards has one kind of discretion in the sense that he must exercise judgment. An administrator whose decision is unreviewable has discretion in a second sense. And an administrator whose decision "is simply not bound by standards set by" authority exercises a third kind of discretion. Id. at 33.

Dworkin's first and third forms of discretion are related in that they both depend on the extent to which an administrator's decision is controlled by standards set by superior authorities. Whenever the rules and standards that guide adjudicative decision-makers are highly general, the decision-makers applying them either make policy, however unconsciously, or make the decision arbitrarily. This authority to make policy in the adjudicative setting is the essence of adjudicative discretion. See $\mathrm{L}$. JAFFE, Judicial CoNTrol of ADMINISTRATIVE ACTION 586 (1965) (defining administrative discretion as "the power of the administrator to make a choice from among two or more legally valid solutions"). The entitlement analysis for due process utilizes discretion in this sense.

6. See generally Van Alstyne, The Demise of the Right-Privilege Distinction in Constitutional Law, 81 HARv. L. REv. 1439, 1439-45 (1968) [hereinafter cited as Van Alstyne, Right-Privilege Distinction]; Van Alstyne, Cracks in "the New Property": Adjudicative Due Process in the Administrative State, 62 CoRNEll L. REv. 445, 447-49 (1977) (noting that eradication of right-privilge distinction for purposes of government action that burdened specific constitutional rights did not eradicate distinction for purposes of procedural due process) [hereinafter cited as Van Alstyne, Cracks in the "New Property"].

Additionally, self-imposed "hands off" doctrines largely precluded judicial review of power exercised in schools, see Buss, Procedural Due Process for School Discipline: Probing the Constitutional Outline, 119 U. PA. L. REv. 545, 559-73 (1971) (discussing balancing of hands-off doctrine with more modern, activist approach), and prisons, see Note, Beyond the Ken of the Courts: A Critique of Judicial Refusal to Review the Complaints of Convicts, 72 YALE L.J. 506 (1963).

7. The lead decision, Goldberg v. Kelly, 397 U.S. 254 (1970), relied in part on a statutory entitlement to welfare benefits as the basis for the property interest. Id. at 262 . In Bell v. Burson, 402 U.S. 
In recent years, however, the Supreme Court has contracted the due process frontier by enforcing a highly formalistic entitlement approach. ${ }^{8}$ Only if a rule provides substantive criteria that limit an administrator's discretion to withhold or revoke some interest does an individual have an entitlement protected by due process. ${ }^{\ominus}$ While any form of government rule may create an entitlement-even a policy statement promulgated by the very government officials who apply it $^{10}$-it must be mandatory. Thus, rules that provide standards to guide discretion will generally not invoke due process protection if they provide only that administrators "may" make a decision on the basis of these standards. ${ }^{11}$

535, 539 (1971), however, the Court held that the suspension of a driver's license required due process protection solely because of its importance. In Morrissey v. Brewer, 408 U.S. 471, 481-82 (1972), the Court held parole release protected by due process on the grounds that it included many of the "core values of unqualified liberty and its termination inflicts a 'grievous loss' on the parolee and often on others."

8. The Court first enunciated the entitlement analysis in Board of Regents v. Roth, 408 U.S. 564, 577 (1972), which held that property rights invoking due process are created and defined by positive law. For other kinds of property interests to which the Supreme Court has applied the entitlement analysis, see Cleveland Bd. of Educ. v. Loudermill, 105 S. Ct. 1487, 1491-93 (1985) (civil service employment); Logan v. Zimmerman Brush Co., 455 U.S. 422, 428-33 (1982) (right of action to obtain administrative remedy for employment discrimination); Barry v. Barchi, 443 U.S. 55, 64 (1979) (horse trainer's license); Leis v. Flynt, 439 U.S. 438, 441-43 (1979) (lawyer's permission to appear pro hac vice in state court); Memphis Light, Gas \& Water Div. v. Craft, 436 U.S. 1, 9 (1978) (continued receipt of electrcity); Goss v. Lopez, 419 U.S. 565, 572-73 (1975) (public school attendance). The Supreme Court has held that due process protection for liberty interests also depends on their recognition in positive law and has applied this principle primarily in prison cases. See, e.g., Greenholtz v. Nebraska Penal Inmates, 442 U.S. 1, 11-16 (1979) (parole release); Meachum v. Fano, 427 U.S. 215, 223-27 (1976) (transfer to administrative segregation); Wolff v. McDonnel, 418 U.S. 539, 557 (1974) (prison good-time credits); see also Paul v. Davis, 424 U.S. 693, 710-12 (1976) (public identification on list of active shoplifters).

9. While purely procedural rules will not create due process rights, see Olim v. Wakinekona, 461 U.S. 238, 248-51 (1983), rules that substantively limit a decisionmaker's discretion will, see Hewitt v. Helms, 459 U.S. 460, 471-72 (1983). The substantive criteria need not be detailed, however. Even a civil service regulation that prevents a dismissal except "for cause," with no elaboration on what constitutes "cause," creates a due process entitlement. See Arnett v. Kennedy, 416 U.S. 134, 151-52 (1974) (opinion of Rehnquist, J.). This leniency suggests that the Court has arrived at the entitlement test by attempting to define "life, liberty or property," not by an explicit conclusion that unfettered discretion makes due process unnecessary.

10. For a good review of the recent cases on prison policy statements, see Lucas v. Hodges, 730 F.2d 1493, 1502-06 \& nn.17-21 (D.C. Cir.) (prison policy statements create liberty interest if they "have been read . . . as limiting the discretion of the ultimate decision-makers," but not if "they are interpreted merely as guidelines"), vacated as moot, 732 F.2d 1392 (D.C. Cir. 1984).

11. The requirement for mandatory language has been expressed by the Supreme Court most explicitly in cases affecting prisoners. See, e.g., Connecticut Bd. of Pardons v. Dumschat, 452 U.S. 458, 463-466 (1981) ("The Connecticut commutation statute, having no definitions, no criteria, and no mandated 'shalls,' creates no analagous duty or constitutional entitlement."); Greenholtz, 442 U.S. at 11-12 (focusing on unique mandatory "structure and language" of Nebraska parole statute); Parker v. Corrothers, 750 F.2d 653, 657 \& n.4 (8th Cir. 1984) (holding "shall/may language" at least "important factor" in determination of liberty interest and citing cases considering this langugage "talismanic"). Compare Solomon v. Elsea, 676 F.2d 282, 284-85 (7th Cir. 1982) (entitlement in federal parole system) with Boothe v. Hammock, 605 F.2d 661 (2d Cir. 1979) (no entitlement to parole release under New York law despite almost identical statutory standards and similar guideline system as in federal system because New York parole statute lacks mandatory language). Cases dealing with property interests, however, also require mandatory language. See, e.g., Davis v. Ball Memorial Hosp. Ass'n, 640 F.2d 30, 41 (7th Cir. 1980) (entitlement to medical care exists only if right to 
The Supreme Court has recognized a few exceptions to the entitlement analysis. A mutual understanding (in the nature of an implied contract) may create a property interest, ${ }^{12}$ injury to reputation may violate a liberty interest, ${ }^{13}$ and some liberty interests are so fundamental that they invoke due process protection even without statutory or regulatory recognition. ${ }^{14}$

its receipt depends entirely on controvertible facts); Jacobson v. Hannifin, 627 F.2d 177, 180 (9th Cir. 1980) (entitlement to gaming license depends largely on existence of "mandatory language" in statute).

Some members of the Supreme Court have suggested broader versions of an entitlement analysis that does not require mandatory language. In Leis $v$. Flynt, Justice Stevens, speaking for four justices in dissent, rejected the majority's holding that Ohio law did not create a due process entitlement to a lawyer's appearance in its courts pro hac vice. 439 U.S. at 454 (1979). Justice Stevens argued, "[w]hile it is unquestionably true that an Ohio trial judge has broad discretion," Ohio law permitted higher court reversal and thus the trial judge "had no power to act arbitrarily." Id. at 455. He argued that this restriction created a property right protected by due process. But neither a Supreme Court majority nor the vast majority of lower courts have proved willing to recognize entitlements merely because of some limitation on discretion; they have required that benefits automatically follow the satisfaction of specified criteria.

12. See Perry v. Sinderman, 408 U.S. 593 (1972) (property interest recognized in continued employment). But see Jago v. Van Curren, 454 U.S. 14, 18-21 (1981) (per curiam) (mutual understandings can create property but not liberty interest). Thus, courts sometimes hold that those receiving benefits have entitlements to their continuation even in the absence of mandatory rules. See, e.g., Stoller v. College of Medicine, 562 F. Supp. 403, 412 (M.D. Pa. 1983) (property right to continued medical education), aff'd mem., 727 F.2d 1101 (3d Cir. 1984); Lopez v. Henry Phipps Plaza South, Inc., 498 F.2d 937 (2d Cir. 1974) (custom of renewal means existing public tenants have due process rights in lease renewal); Martin v. Helstad, 578 F. Supp. 1473, 1480 (W.D. Wis. 1983) (although no statutory entitlement to law school admission, acceptance creates entitlement).

13. In Wisconsin v. Constantineau, 400 U.S. 433, 437 (1971), the Court held: "Where a person's good name, reputation, honor, or integrity is at stake because of what the government is doing to him, notice and an opportunity to be heard are essential." Although Paul v. Davis, 424 U.S. 693 (1976), limited this liberty right to injuries to reputation that accompany some change in legal status, a denial of a government benefit that is not itself a protected property interest infringes on protected liberty if the government publicly disseminates a stigmatizing reason. See, e.g., Doe v. United States Dept. of Justice, 753 F.2d 1092 (D.C. Cir. 1985) (discharge from public employment for publicly disclosed, defamatory reasons infringes on protected liberty interest); Old Dominion Dairy Products v. Secretary of Defense, 631 F.2d 953 (D.C. Cir. 1980) (although no protected property interest in government contracts, "stigmatizing' governmental defamation having an immediate and tangible effect" on contractor's business infringes protected liberty interest); Greenhill v. Bailey, 519 F.2d 5, 8 (8th Cir. 1975) (dismissal from school on claim of lack of "intellectual ability" infringes on protected liberty interest).

14. Thus, the Supreme Court has mandated procedures for probation, Gagnon v. Scarpelli, 411 U.S. 778, 781-82 (1973), and parole revocation, Morrissey v. Brewer, 408 U.S. 471, 481-82 (1972), and for the transfer of a prison inmate to a mental institution, Vitek v. Jones, 445 U.S. 480,494 (1980). The right to pursue a chosen profession is also considered fundamental and will invoke due process entitlements to virtually all forms of professional licensing. See Willner v. Committee on Character \& Fitness, 373 U.S. 96, 102 (1963) (due process protects application for bar membership); Fleming v. U.S. Dept. of Agriculture, 713 F.2d 179, 183 (6th Cir. 1983) (treating revocation of horse training license as intrusion on "right to practice a chosen profession"). This right may even command a fair admission procedure to a graduate school if that school plays a crucial role in entry into the chosen profession. See Grove v. Ohio State Univ., College of Veterinary Medicine, 424 F. Supp. 377, 382-83 (S.D. Ohio 1976). 
But the Supreme Court invokes these exceptions infrequently, ${ }^{15}$ and lower courts have begun to apply the entitlement analysis with rigor. ${ }^{18}$

The entitlement approach leads to ironic results. If parole boards, business licensing commissions, or social security officials exercise standardless discretion, unencumbered by procedures, and without obligations to explain their decisions, they have no constitutional obligation to follow careful procedures. But if they already implement specific statutory, regulatory or internal standards and procedures, they must also follow the extra requirements of due process. ${ }^{17}$ In Hewitt $v$. Helms ${ }^{18}$ Justice Rehnquist noted the paradox of inferring due process rights from procedural rules:

The creation of procedural guidelines to channel the decisionmaking of prison officials is, in the view of many experts in the field, a salutary development. It would be ironic to hold that when a State embarks on such desirable experimentation it thereby opens the door to scrutiny by the federal courts, while States that choose not to adopt

15. In Barry v. Barchi, 443 U.S. 55, 64 \& n.11 (1979), for example, the Supreme Court concluded that a horse trainer had a right to due process before suspension of his racing license only after examining the statute that granted him the license. The Court did not assume either that the suspension called for due process because it deprived the trainer of his fundamental right to practice his chosen profession or that the license necessarily became a property interest once the trainer had received it. In Leis v. Flynt, 439 U.S. 438, 442-43 (1979) (per curiam), the Court held that out-of-state lawyers had no entitlement under Ohio law to appear in Ohio courts pro hac vice. The dissenters argued that the attorneys' interest in discharging their professional responsibility "for the fair administration of justice" was automatically worthy of due process protection. Id. at 452-53 (Stevens, J., dissenting).

16. Zoning cases provide one example of the new rigor. Traditionally, the courts have assumed that due process protects all applications for zoning variances without examining state law. See, e.g., Sixth Camden Corp. v. Township of Evesham, 420 F. Supp. 709, 718-19 (D.N.J. 1976) (assuming property right mandating due process in denial of zoning variance without any discussion of state law); Adler v. Lynch, 415 F. Supp. 705, 709 \& n.4 (D. Neb. 1976) (recognizing property right requiring procedural due process in consideration of zoning variance application despite permissive statutory language). In City of Eastlake v. Forest City Enter., 426 U.S. 668 (1976), the Supreme Court itself failed to apply the entitlement analysis to a zoning case. See id. at 680-82 (Stevens, J., dissenting) (discussing majority's omission). Many recent cases, however, have applied the entitlement analysis to applications for zoning variances and building permits. See, e.g., Littlefield v. City of Afton, 785 F.2d 596, 601-02 (8th Cir. 1986) (finding property right to building permit under Minnesota law); Marino v. McDonald, 611 F. Supp. 848 (E.D. Mich. 1985) (no property right to special land use permit under Michigan law).

17. Compare Jacobson v. Hannifin, 627 F.2d 177, 180 (9th Cir. 1980) (no entitlement to gaming license under Nevada law) and Soderback v. Siler, 610 F.2d 643, 646 (9th Cir. 1979) (no entitlement to merchant marine officer license) and Medina v. Rudman, 545 F.2d 244, 250-51 (1st Cir. 1976) (no entitlement to racing license under New Hampshire law), cert. denied, 434 U.S. 891 (1977) with Barry v. Barchi, 443 U.S. 55, 64 \& n.11 (1979) (New York law creates due process entitlement to maintenance of racing license). Compare Meachum v. Fano, 427 U.S. 215, 223-27 (1976) (no due process rights before imposition of prison segregation) with Bills v. Henderson, 631 F.2d 1287, 1291-94 (6th Cir. 1980) (regulations create due process entitlement before transfer to segregation). For a comparison of different parole cases, see N. Cohen \& J. Gobert, The Law of Probation AND PAROLE $\S 3.13$ (1983 \& Supp. 1984) (majority of parole statutes held too discretionary to create entitlement).

18. 459 U.S. 460 (1983). 
such procedural provisions entirely avoid the strictures of the Due Process Clause. ${ }^{19}$

More generally, the same paradox occurs if courts infer due process rights from the existence of state substantive guidelines; they also channel administrative discretion, and they also are "a salutary development."

A second result of the entitlement analysis is that it enables the political apparatus to deny procedural due process protection to virtually any interest not protected by another constitutional right. The government may leave people an unfettered right to build a house. Alternatively, the government may pass strict zoning laws that make building a "benefit" dependent on the receipt of a license or variance. ${ }^{20}$ Government may grant authority over actual prison sentences to a judge, whose decisions to incarcerate "deprive" liberty as a "right." Alternatively, government may create a system in which judges sentence wrongdoers to unrealistically long prison terms so that actual lengths of incarceration are determined by a parole board. These decisions then "grant" liberty as a "benefit."21 By shifting a liberty or property interest from a right to a benefit, the political branches may deprive individuals of that interest without following due process merely by granting administrators broad discretion.

Finally, a third result of the entitlement analysis, as Justice Rehnquist implied, is that it discourages administrative agencies and even legislatures from establishing rules that control adjudicative discretion. By establishing rules that limit discretion, an agency or legislature may bring upon itself unwanted burdens including: constitutionally required procedures more extensive than those they wish to provide; ${ }^{22}$ a federal cause of action any time those procedures are not followed; potential court challenges to the

19. Id. at 471 .

20. For a discussion of the courts' general, but disappearing, reluctance to apply the entitlement analysis to zoning cases, see supra note 16.

21. The federal parole system, for example, uses parole not to reward prisoners for rehabilitation but principally to check sentencing disparity. See United States v. Addonizio, 442 U.S. 178, 188-89 (1979). The main criteria involved in the parole decision, the severity of the offense and characteristics of the prisoner's background, see 18 U.S.C. $\S$ 4206(a) (1982), are the same factors entering most judges' sentencing decisions. Even the principal source of the United States Parole Commission's information, the Pre-Sentence Investigation Report, is the same source relied on by the sentencing judge. See Dufresne v. Baer, 744 F.2d 1543, 1547 (11th Cir. 1984). The recent decision by Congress to abolish parole, which it viewed as part of the sentencing process, by replacing it with a system of sentencing guidelines, see Sentencing Reform Act of 1984, Pub. L. No. 98-473, 98 Stat. 1987 (1984) (to be codified in scattered sections of 18 U.S.C.) - in part because of concerns over sentencing disparity notwithstanding parole, see S. Rep. No. 98-225, 98th Cong. 2d Sess. 38, 46, reprinted in 1984 U.S. CodE CoNG. \& AD. NEws 3182, 3221, 3229-demonstrates the interchangeability of parole and direct sentencing.

22. In Cleveland Bd. of Educ. v. Loudermill, 105 S. Ct. 1487, 1493-95 (1985), for example, a civil service statute provided that an employee could be dismissed only for cause but provided no form of hearing before termination. The Supreme Court held that due process mandated a pretermination hearing. 
substance of a decision on the grounds that no evidence supported it: ${ }^{23}$ and, perhaps most distasteful from the perspective of government officials, the possibility of personal liability for government officials any time they fail to follow constitutionally mandated procedures. ${ }^{24}$ In a pointed example of the way the rule distorts incentives, the Association of State Attorneys General has encouraged state prison agencies not to establish rules and standards as a way of avoiding due process review. ${ }^{25}$

\section{The Impact of Administrative Discretion on the Determination of What Process is Due}

Once a claimant establishes a right protected by due process, a court must decide what process is "due." The existence of mandatory procedures may help establish a due process entitlement, ${ }^{28}$ but the Constitution neither gives an individual the right to have those procedures followed nor does it restrict an individual's rights only to those procedures. The constitutional requirements of due process are independent.

The Supreme Court has emphasized that the "fundamental requirement of due process is the opportunity to be heard 'at a meaningful time and in a meaningful manner," the hearing required are flexible. ${ }^{28}$ The requirements usually depend on

23. See Superintendent, Mass. Corr. Inst. v. Hill, 105 S. Ct. 2768, 2773-75 (1985) (due process commands substantive judicial review to determine if "some evidence" supported decision to revoke prison good time credits) (citing cases).

24. Section 1983, of Title 42 U.S.C. (1982), makes a state official acting under color of state law liable for violating any constitutional right. Accordingly, an administrator may be liable for failing to afford a claimant full due process rights. See Carey v. Piphus, 435 U.S. 247 (1978) (school officials liable for violations of procedural due process but only for nominal damages in absence of proof of actual injury); Haygood v. Younger, 769 F.2d 1350, 1355-58 (9th Cir. 1985) (en banc) (affirming damage recovery under $\S 1983$ in part because failure to afford prisoner meaningful hearing about disputed time of release led to overcalculation of prison term).

Ira Kirschbaum, longtime Deputy General Counsel to the United States Bureau of Prisons, reports that his office is concerned about creating due process entitlements through prison disciplinary rules primarily because of the possibility of damage suits. He does not believe that this burden has dissuaded the Bureau from developing more detailed rules, however, and points to the increasing complexity of federal prison policy statements. Telephone Interview with Ira Kirschbaum, Deputy Gencral Counsel of the U.S. Bureau of Prisons (June 7, 1985).

25. Committee on the Office of Attorney General, National Association of Attorneys General, Administrative Segregation of Prisoners: Due Process Issues 38 (1979). This pamphlet also argues that administrative segregation is generally inappropriate for due process restrictions.

26. Hewitt v. Helms, 459 U.S. 460, 471-72 (1983) (mandatory procedures combined with "substantive predicates" create due process entitlement).

27. See Mathews v. Eldridge, 424 U.S. 319, 333 (1976) (quoting Armstrong v. Manzo, 380 U.S. $545,552(1965))$.

28. For this proposition, courts often cite Cafeteria \& Restaurant Workers Union v. McElroy, 367 U.S. 886, 895 (1961).

Notwithstanding the "flexibility" of due process, courts invariably require that the administrative process adopt some of the elements of the traditional judicial hearing. In a famous article, the late Judge Henry Friendly listed eleven possible elements to a hearing: (1) an unbiased tribunal, (2) notice of the proposed action and grounds asserted for it, (3) an opportunity to present arguments why 
the courts' evaluation of three factors: the individual's interest at stake, the government's interest in avoiding the encumbrance of additional process, and the potential contribution of that process to the prevention of erroneous decisions. ${ }^{29}$

Lower courts rarely balance these three factors on their own but instead analogize their cases to the facts of earlier Supreme Court decisions. These decisions have not treated administrative discretion with complete consistency. In some "benefits" cases, the Supreme Court has suggested that a decisionmaker's broad discretion reduces the need for procedural protections. Thus, in Greenholtz $v$. Inmates of the Nebraska Penal and Correctional Complex, ${ }^{30}$ the Supreme Court relied heavily on the "subjective" and "predictive" nature of the parole release decision to explain why the Constitution requires only limited procedures and, in particular, why the Constitution does not require a parole board to furnish an inmate with a summary of the information it relied on in denying parole. ${ }^{31}$ Similarly, in Board of Curators of the University of Missouri v. Horowitz, ${ }^{32}$ the Supreme Court refused to require even "an informal give and take" before school officials dismiss a student for poor academic performance. "Such a judgment is by its nature more subjective and evaluative than the typical factual questions presented in the average disciplinary decision."ss

In other benefits cases, including several decided in the 1984 term, the Court has recognized that due process protections are necessary to ensure the informed exercise of discretion. Thus, regardless of a judge or parole board's discretion, a "parolee or probationer is entitled to an opportunity to show not only that he did not violate [parole] conditions, but also that there was a justifiable excuse for any violation or that revocation is not the appropriate disposition."34 In Dixon v. Love, ${ }^{35}$ the Court went so far as to point out that broad, case-by-case discretion over the suspension of

the proposed action should not be taken, (4) the right to call witnesses, (5) knowledge of the evidence against one, (6) decisions based only on evidence presented, (7) the right to counsel, (8) the making of a record, (9) a statement of reasons for the government's position, (10) public attendance, (11) judicial review. Friendly, "Some Kind of Hearing," 123 U. PA. L. REv. 1267, 1279-95 (1975).

29. Mathews v. Eldridge, 424 U.S. at 335.

30. 442 U.S. 1 (1979)

31. Id. at 13-16; see also Dumschat, 452 U.S. at 464 (decision to commute sentence not appropriate for due process requirements because it "generally depends not simply on objective factfinding, but also on purely subjective evaluations and on predictions of future behavior").

32. 435 U.S. 78 (1978).

33. Id. at 90 .

34. Black v. Romano, 105 S. Ct. 2254, 2258 (1985); see Loudermill, 105 S. Ct. at 1494 ("Even where the facts are clear, the appropriateness or necessity of the discharge may not be ... ." due process requires "meaningful opportunity to invoke the discretion of the decisionmaker."); Goss v. Lopez, 419 U.S. 565, 584 (1975) (hearing necessary before suspension even if basic facts are clear, to permit student "to characterize his conduct and put it in what he deems the proper context"); Gagnon v. Scarpelli, 411 U.S. 778, 787 (1973) (indicating due process concern for "informed use of discretion").

35. 431 U.S. 105 (1977) 
driver's licenses would reduce fairness and promote unequal treatment; ${ }^{36}$ accordingly, the lack of discretion under Illinois law made a pretermination hearing unnecessary. ${ }^{37}$ In no cases involving only the loss or gain of a benefit, however, has the Supreme Court mandated procedures to compensate for the dangers of discretion..$^{38}$

In contrast to the Supreme Court, a few lower courts have held that a complete lack of agency standards violates due process and have ordered the promulgation of meaningful standards. But these rulings make up no regular part of the judicial arsenal; they come only in clumps limited to similar fact patterns. ${ }^{30}$ More significantly, the entitlement analysis largely forecloses this approach by depriving courts of the power to order standards in the specific situations most requiring them. The Supreme Court has reversed a lower court decision ordering a promulgation of standards exactly because the need for standards indicated the lack of entitlement. ${ }^{40}$

Though the most recent Supreme Gourt cases recognize the importance of the informed exercise of discretion, ${ }^{41}$ virtually no "benefits" cases discuss the dangers posed by broad adjudicative discretion. This failure is puzzling because the Court has recognized these dangers so clearly in the context of the void-for-vagueness doctrine.

\section{Id. at 115 .}

37. Id. at 113-14.

38. Of course, if the lack of standards creates a substantial possibility that benefits will be revoked for constitutionally impermissible reasons, the Supreme Court will scrutinize for vagueness. See, e.g., Arnett v. Kennedy, 416 U.S. 134 158-63 (1974) (portion of opinion joined by all justices) (examining claimed impingement on free speech). See generally infra note 55 (discussing courts' lesser tolerance for vagueness if it threatens constitutionally protected conduct).

39. A leading case cited in many administrative law treatises is Holmes v. New York Hous. Auth., 398 F.2d 262 (2d Cir. 1968). The court there held a public housing agency in violation of due process for failing to establish any standard, even a lottery standard, for processing applications for public housing. Id. at 265. Only a small number of cases have cited and followed Holmes, however, and those have almost invariably dealt with other forms of government welfare benefits. See Carey v. Quern, 588 F.2d 230, 232 (7th Cir. 1978) (clothing allowance); White v. Roughton, 530 F.2d 750, 753 (7th Gir. 1976) (general welfare assistance).

A second case cited in many law treatises is Hornsby v. Allen, 326 F.2d 605 (5th Cir. 1964). It ordered a local liquor commission to grant all applications for liquor licenses until it established standards on which to base denials. Apart from Holmes, the only cases citing and following Hornsby, have been liquor licensing decisions within the Fifth Circuit's jurisdiction. See, e.g., Bloch v. Thompson, 472 F.2d 587 (5th Cir. 1973); Johnson v. Brown, 584 F. Supp. 510 (M.D. Ga. 1984).

In addition, a line of cases has applied the void-for-vagueness doctrine to the revocation of government benefits, principally business and professional licenses. See infra note 60 .

40. Leis v. Flynt, 439 U.S. at 441-43. Accordingly, the Second Circuit has repudiated its prior reasoning in Holmes, see Phelps v. Housing Auth. of Woodruff, 742 F.2d 816, 822-23 \& n.11 (1984), and the Seventh Circuit has overruled its decision in Roughton, Davis v. Ball Memorial Hosp. Ass'n, 640 F.2d 30, 39-40 (7th Cir. 1980). But c.f. Baker-Chaput v. Cammett, 406 F. Supp. 1134, 1139 (D.N.H. 1976) (finding entitlement to welfare benefits but contradictorily ordering standards to control defendants' "unfettered and unguided discretion").

41. See supra note 34. 


\section{The Dangers of Discretion-The Void-For-Vagueness DOCTRINE}

The legendary case of Yick Wo v. Hopkins ${ }^{42}$ found two faults with San Francisco's administrative system for licensing city laundries. The city Board of Supervisors' discriminatory refusal to license Chinese-Americans provided one constitutional violation for which the decision is well remembered. But the Court wrote at greater length and with greater passion on another problem. Because no statutory standards guided the Board's authority, the Board's discretion was "a naked and arbitrary power to give or withold consent"43 which directly conflicted with "the nature and theory of our institutions of government." 14 The threat of decisions arising from "enmity or prejudice, from partisan zeal or animosity, from favoritism and other improper influences and motives easy of concealment" made the law unconstitutional. ${ }^{45}$ That the ensuing decisions did arise from prejudice provided only an additional basis of unconstitutionality.

The portion of Yick Wo focusing on the dangers of unfettered discretion has evolved into the void-for-vagueness doctrine. Arising out of the due process clauses, ${ }^{48}$ this doctrine prohibits criminal and civil penalties for violations of laws-statutory or regulatory-that leave the standards for proscribed conduct exceptionally broad or unclear. ${ }^{47}$ Although courts apply void-for-vagueness chiefly to criminal and quasi-criminal laws, its rationales apply also to the adjudication of government benefits.

In part, void-for-vagueness assures fair warning before government punishment. Fair warning maximizes liberty of action and assures fundamental fairness by assuring people that they will not be punished for behavior the government has not explicitly condemned.8 Although the denial of a benefit may not be punishment in a criminal sense, the loss of a

42. 118 U.S. 356 (1886).

43. Id. at 366 .

44. Id. at 369 .

45. Id. at 370 .

46. In Yick Wo, the Court held that the lack of standards violated the Fourteenth Amendment in general and did not specify any particular clause. The void-for-vagueness cases leave no doubt that the constitutional restriction emanates from the due process clause.

47. In general, courts have tried to avoid invalidating vague statutes, developing a number of theories to save them. Courts grant statutes a strong presumption of validity and will not invalidate them because of difficulty in determining whether marginal offenses fall within their language. See United States v. National Dairy Products, Corp., 372 U.S. 29, 32 (1963). Economic regulations receive special deference because businesses "can be expected to consult relevant legislation in advance of action," as do laws punishable only by civil penalties because the consequences of imprecision are "qualitatively less severe." Village of Hoffman Estates v. Flipside, Hoffman Estates, Inc., 455 U.S. $489,498-99$ (1982) (citations omitted). And in a facial challenge to a vague law, courts will uphold a law if it is valid in any of its applications unless it reaches "constitutionally protected conduct." Id. at 494-95.

48. See Grayned v. City of Rockford, 408 U.S. 104, 108 \& n.3 (1972) (citing cases). 
benefit can be substantial. Thus, even in the context of benefits, a lack of standards threatens that people will be disadvantaged for conduct the government has not condemned or suggested is inappropriate for the recipient of a particular benefit.49

The second and primary ${ }^{50}$ rationale for void-for-vagueness expresses the same general judgment about the dangers of unguided discretion articulated so eloquently in Yick Wo. As the Supreme Court wrote in Grayned v. City of Rockford: "A vague law impermissibly delegates basic policy matters to policemen, judges, and juries for resolution on an ad hoc and subjective basis, with the attendant dangers of arbitrary and discriminatory application."'31 This danger of unequal distribution of advantages and disadvantages applies equally to the distribution of benefits.

Although present in all methods of policy-making, the risk of arbitrariness and discrimination is highest in adjudication. Legislation, and to some extent administrative rulemaking, operate openly and prospectively through rules of general scope, thereby diminishing the possibility that government will single out an individual for vindictive or unfair treatment. Those affected have political strength in numbers to protect their interests and to keep rule-makers accountable. ${ }^{52}$ Policy-making in an adjudicative setting, however, occurs retrospectively, with the interests of known individuals at stake, and therefore with the increased danger that the policy developed in separate cases will be vindictive and unequal. Because it may operate differently on different individuals, it may fracture group cohesion and leave the isolated individual with little political power to protect her interests. Because policy decisions may go unspoken, they may be highly antithetical to social-even constitutional-values. Thus, as an influential commentary has summarized, a lack of standards makes decisions "responsive to whim or discrimination unrelated to any specific determination of need by the responsible policy-making organs of soci-

49. The doctrine that prohibits denial of a benefit for constitutionally impermissible reasons recognizes that the loss of a benefit can be a major disadvantage. See Van Alsyne, Right-Privilege Distinction, supra note 6. Furthermore, although vague laws threaten grievous loss for conduct the government has not explicitly condemned, the laws that do not create entitlements have no standards at all and so threaten grievous loss for conduct the government has not condemned even remotely. As the Supreme Court has explained in a slightly different context, "To punish a person because he has done what the law plainly allows him to do is a due process violation of the most basic sort." Bordenkircher v. Hayes, 434 U.S. 357, 364 (1978). For further discussion of the relevance of fair warning to government benefits, see infra notes 84-91 and accompanying text.

50. The Supreme Court has held that the "more important" purpose of void-for-vagueness doctrine is "the requirement that a legislature establish minimum guidelines to govern law enforcement," Kolender v. Lawson, 461 U.S. 352, 358 (1983), thereby preventing "arbitrary and discriminatory enforcement," id. at 357.

51. 408 U.S. 104, 108-09 (1972) (citing cases).

52. Equal protection and substantive due process can protect insular minorities from victimization. United States v. Carolene Products Co., 304 U.S. 144, 152 n.4 (1938). 
ety." ${ }^{\text {"5s }}$ A lack of standards undermines the due process command that procedures assure "a certain overall probability of regularity."

Courts have demonstrated special concern for vagueness when government action threatens specific constitutional rights ${ }^{55}$ or life itself. ${ }^{58}$ These cases represent a heightened scrutiny for vagueness to protect vital personal interests. ${ }^{.7}$ But even using the weakest test courts have established for unconstitutional vagueness - the test which provides that laws are unconstitutional only if "no standard of conduct is specified at all" - the typical grant of authority evading due process review fails. An individual lacks an entitlement exactly when he can meet no set of criteria entitling him to the desired government benefit because an administrator can deny the benefit for any reason or "for no reason at all." exempt from due process scrutiny is the same kind of unconstrained power to distribute government benefits condemned by the Court in Yick Wo.

Ironically, however, the existence of unfettered discretion in the granting of government "benefits" does not technically violate the void-for-

53. Note, The Void-for-Vagueness Doctrine in the Supreme Court, 109 U. PA. L. REv. 67, 90 (1960) (written by now-Professor Anthony Amsterdam). As of the end of the 1984 term, nineteen Supreme Court opinions by a variety of justices have cited this Note.

54. Id. at 89 (emphasis in original).

55. Courts invoke the "overbreadth" doctrine frequently to strike down vague statutes that potentially infringe on freedom of speech or association. See generally Note, The First Amendment Overbreadth Doctrine, 83 HARv. L. REv. 844, 856-58 (1970) (placing First Amendment vagueness cases in context of general overbreadth concern of "chilling effect" on protected speech). A number of cases, many constitutional tort suits, have also focused on the elimination of vagueness in rules necessary to protect Fourth Amendment rights or due process rights to criminal discovery. See Marshall v. Barlow's, Inc., 436 U.S. 307, 323 \& n.20 (1978) (OSHA entitled to search warrant without probable cause only if "pursuant to an administrative plan containing specific neutral criteria"); United States v. Bryant, 439 F.2d 642, 652 (D.C. Cir. 1971) (ordering investigative agencies to establish rules ensuring preservation of all discoverable evidence).

56. Concerned with arbitrariness, the Supreme Court has held that governments can only impose the death penalty if they provide clear standards for jury and judge. Furman v. Georgia, 408 U.S. 238 (1972) (opinions of Douglas, Stewart, White, JJ.); see also Gregg v. Georgia, 428 U.S. 153, 189 (1976) (opinion of Stewart, Powell, Stevens, JJ.) ("[W]here discretion is afforded a sentencing body on a matter so grave as the determination of whether a human life should be taken or spared, that discretion must be suitably directed and limited so as to minimize the risk of wholly arbitrary and capricous action."); id. at 220-30 (White, J., concurring). More recent Supreme Court cases may indicate, however, that the Court pays only lip service to this demand for limits on discretion. See The Supreme Court, 1982 Term, 97 HARv. L. REv. 71, 118-27 (1983).

57. See generally United States v. Robel, 389 U.S. 258, 275 (1967) (Brennan, J., concurring) (arguing that standard for indefiniteness should be stricter for statutes infringing on constitutionally protected liberty).

58. See Smith v. Gogruen, 415 U.S. 566, 578 (1974) (citing Coates v. City of Cincinnati, 402 U.S. $611,614(1971))$.

59. See Olim v. Wakinekona, 461 U.S. 238,249 (1983) ("If the decisionmaker . . . "can deny the requested relief for any constitutionally permissible reason or for no reason at all,' the State has not created a constitutionally protected liberty interest.") (citing Dumschat, 452 U.S. at 467 (Brennan, J., concurring)); Meachum v. Fano, 427 U.S. 215, 228 (1976) (no liberty infringement in prison transfer "so long as prison officials have discretion to transfer . . . for whatever reason or for no reason at all'). 
vagueness doctrine. Because void-for-vagueness is a doctrine of due process, it comes into play only if an individual can demonstrate a property or liberty entitlement. But, under the present Supreme Court approach, an entitlement exists only if standards confine administrative discretion. Thus, unless standards control the administration of a government program, an individual has no constitutional right to have the program administered with standards. ${ }^{80}$

Even though the "void-for-vagueness" doctrine is technically consistent with the entitlement analysis, the policies of the two directly conflict. If the former is correct that unfettered discretion undermines the due process demand for a "probability of regularity"11 in decisions affecting important individual interests, ${ }^{62}$ the present analysis of procedural due process is deeply flawed.

\section{Defenses of the Gourts' Treatment of Discretion}

The failure of procedural due process to deal with the dangers of broad administrative discretion would not condemn the courts' analysis if other justifications outweighed it. This Section will examine and reject various justifications offered to support the entitlement analysis and the concommittant hands-off approach to discretionary agency decisions.

60. A few lower courts have applied void-for-vagueness to benefits with more or less attention to the existence of a property or liberty entitlement, citing both fair warning and rational enforcement concerns. Most of these cases concern the revocation of business or professional licenses. E.g., Housworth v. Glisson, 485 F. Supp. 29, 38 (N.D. Ga. 1981) (ordinance permitting revocation of business license held unconstitutionally vague without discussion of property or liberty interest); Tuma $\mathbf{v}$. Board of Nursing, 100 Idaho 74, 593 P.2d 711 (1979) (statute held void-for-vagueness as applied to revocation of nurse's license thereby infringing on right to practice chosen profession). Some cases, although not focusing on the existence of any protected right, might be justified as infringements on first amendment rights like freedom of association. E.g. Alladin's Castle, Inc. v. City of Mesquite, 434 F. Supp. 473,476 (N.D. Tex. 1977) (finding ordinance denying amusement park license to those with "connection with criminal elements" void-for-vagueness without discussion of due process entitlement).

61. See Note, supra note 53 , at 89 (emphasis omitted).

62. A defender of the courts might argue that the entitlement analysis, applicable only to benefits, does not affect interests approaching the importance of the liberties at stake in most void-for-vagueness cases and that, accordingly, the two doctrines are reconcilable. But the entitlement analysis focuses only on the form of the personal interest, not on its importance. See Board of Regents v. Roth, 408 U.S. 564, 570-71 (1972) ("IT]o determine whether due process requirements apply in the first place, we must look not to the 'weight' but to the nature of the interest at stake.") (emphasis in original). Furthermore, the entitlement analysis permits elective governments to change important rights into benefits. Finally, even if courts should require clear standards only to protect the most important liberty interests, the courts' recognition that vagueness undermines values protected by procedural due process suggests courts should, at a minimum, consider a lack of standards a danger sign requiring compensating procedural checks. 


\section{A. Reasons for Deference to the Political Branches}

Several defenses of the entitlement analysis focus on the merit of having the political branches of government determine whether due process shall attach to a particular interest. One defense states simply that due process protects only life, liberty and property "rights" creation not of judicial divination ${ }^{64}$ but of elective government acting through positive law. ${ }^{65} \mathrm{~A}$ more limited version of this defense suggests that at least to the extent government creates interests, it should have the right to decide if they merit constitutional protection. ${ }^{68} \mathrm{~A}$ slightly different argument that still focuses on the role of the political branches defends the entitlement analysis as a means of limiting due process to interests of true importance to individuals. By protecting only the interests that elective government has defined as rights, the courts will identify important interests yet avoid imposing due process burdens where they do more harm then good. ${ }^{67}$

\section{The Theoretical and Practical Inability to Preserve Due Process as a Constitutional Right}

The first flaw with these "political deference" defenses of the entitlement analysis, as critics across the political spectrum have already argued, ${ }^{68}$ is their theoretical inconsistency. If elective governments create

63. See, e.g., Olim v. Wakinekona, 461 U.S. 238, 250-52 (1983) (due process protects only "substantive rights").

64. See Dumschat, 452 U.S. at 463 (indicating reluctance to spell out "judicially divined 'entitlement" ").

65. See, e.g., Paul v. Davis, 424 U.S. 693, 710 \& n.5 (1976) (interests are "within the meaning of either liberty or property . . by virtue of the fact that they have been initially recognized and protected by state law" or the Bill of Rights); Roth, 408 U.S. at 577 ("Property interests, of course, are not created by the Constitution. Rather, they are created and their dimensions are defined by existing rules or understandings that stem from an independent source such as state law . . . .").

66. This argument is suggested by the Supreme Court's reluctance to apply the entitlement analysis to traditional, common law forms of property. See generally Note, Justice Rehnquist's Theory of Property, 93 Y ALE L. J. 541 (1984) (discussing the Court's inconsistent approach to property rights). The problem with this approach, however, is that no consistent principle, other than age of legal status, distinguishes traditional from "new" property. A merit of the entitlement analysis is its acknowledgment of the impossibility and inadequacy of defining property for constitutional purposes by the traditional, common law.

67. Although he rejects the entitlement analysis, Justice Stevens has suggested this reasoning. See Hewitt v. Helms, 459 U.S. at 488 (Stevens, J., dissenting) ("[B]y limiting the substantive reasons for a transfer to administrative segregation and by establishing procedural protections, these regulations indicate that the state recognizes the substantiality of the deprivation."); see also Easterbrook, Substance and Due Process, 1982 SUP. Cr. REv. 85, 113 ("Procedural rules usually are just a measure of how much the substantive entitlements are worth . . . ."). Whatever the merits of this argument, the Supreme Court's focus on the "nature" not the "wcight" of an interest appears to reject it. Roth, 408 U.S. at 570-71.

68. See Easterbrook, supra note 67; Laycock, Due Process and the Separation of Powers: The Effort to Make the Due Process Clauses Nonjusticiable, 60 TEx. L. REv. 875, 879-82 (1982); Mashaw, Administrative Due Process: The Quest for a Dignitary Theory, 61 B.U.L. REv. 885 
"life, liberty and property" rights, why should those rights include more than the limited procedural protection the governments provide? If courts permit governments to "define" or "create" interests with no protections against arbitrariness, why do they stop governments from "defining" or "creating" interests with only limited protections against arbitrariness?"8

Using entitlements as crude measures of importance does not escape this inconsistency. The determination of what process is due depends on a weighing of the relative importance of individual and government interests and on the probability that a requested procedure will reduce the risk of decisional error. ${ }^{30}$ By inferring the importance of the individual interest from the judgments of the political process, the courts express their unwillingness to second-guess that judgment. But the courts have even less justification for second-guessing the importance of the government interest and the error-reducing value of a requested procedure, for these are matters far more within the government's expertise. ${ }^{71}$ If courts must accept the political judgments of an interest's importance to the individual, they have no legitimate basis for insisting that due process demands procedural protection the government does not already provide. ${ }^{72}$

(1981) (labelling this problem the "positivist trap"); Redish \& Marshall, Adjudicative Independence and the Values of Procedural Due Process, 95 YALE L.J. 455, 466-68 (1986); Tribe, Structural Due Process, 10 Harv. C.R.-C.L. L. Rev. 269, 277-80 (1975); Van Alstyne, Cracks in "The New Property," supra note 6, at 464-65; Williams, Liberty and Property: The Problem of Government Benefits, 12 J. Legal Stud. 3, 6 (1983).

69. Justice Rehnquist, joined at times by three other justices, would solve this inconsistency by holding that claimants to government "benefits" "must take the bitter with the sweet" and be satisfied with the procedures granted them. Arnett v. Kennedy, 416 U.S. 134, 153-54 (1974) (opinion of Rehnquist, J.); see also Goss v. Lopez, 419 U.S. 565, 584 (1975) (Powell, J., dissenting). The essence of Justice Rehnquist's argument is that because liberty and property rights are defined in part by the procedures provided for their protection, due process rights should be coextensive with rights provided by statutes and regulations. But this argument would essentially constitutionalize all statutory and regulatory procedural rules, a development with few advantages and enormous burdens. Every member of the Supreme Court except Justice Rehnquist has now repudiated this idea. See Cleveland Bd. of Educ. v. Loudermill, 105 S. Ct. 1487, 1493 (1985) (blending substantive and procedural rights reduces due process guarantee to "mere tautology"). For a more general discussion of "bitter with the sweet," compare Redish \& Marshall, supra note 68, at 457-68 (objecting to analysis) with Easterbrook, supra note 67 (supporting analysis).

70. Mathews v. Eldridge, 424 U.S. at 334-35.

71. Any idea that courts' traditional expertise over judicial procedures qualifies them to substitute their judgments about the error-reducing value of particular procedures over those of administrators has been refuted by scholarship pointing out the extreme difficulty of the courts' job. See Mashaw, Administrative Due Process As Social-Cost Accounting, 9 Horstra L. Rev. 1423 (1981). The Supreme Court has itself noted that "the judicial mode of an evidentiary hearing [the courts' subject of expertise] is neither a required nor even the most effective, method of decisionmaking in all circumstances." Mathews, 424 U.S. at 348.

72. This argument does not mean that political judgments can provide no guidance for the courts seeking to determine the importance of individual interests. Whether most state governments do or do not provide substantial procedural protection for an interest certainly provides evidence of its importance. See Hewitt, 459 U.S. at 488 (Stevens, J., dissenting). The entitlement analysis is flawed because it obligates courts to accept the political judgment within any given locality of an interest's importance without any inquiry into the possibility of political failure. 


\section{The Conflict With Substantive Due Process}

A more important failing of the "deference" justifications for the entitlement analysis becomes especially evident in a comparison of procedural with substantive due process. In contrast to their procedural due process approach, courts applying a substantive due process analysis to strike down arbitrary or invidious, legislative classifications ${ }^{73}$ have not demanded that these classifications deprive individuals of pre-existing entitlements. Instead, in many cases, the Supreme Court has found classifications invalid exactly because they impermissibly failed to provide an entitlement. ${ }^{74}$ How can these cases be squared with the demand for politically recognized entitlements?75

One argument might be that substantive due process protects only against discrimination, and that a fundamental liberty right to be free from discrimination emanates from the due process clauses or from other constitutional guarantees. ${ }^{76}$ But the term "discrimination" has little inherent meaning. The right to be free from discrimination is only the right not to be disadvantaged for invidious or arbitrary reasons. ${ }^{77}$ In Department of Agriculture v. Moreno, ${ }^{78}$ for example, the Supreme Court applied the due process clause to strike down a law governing the distribution of welfare benefits solely because it distinguished between potential recipients "with-

73. The Court initiated this use of due process in Bolling v. Sharpe, 347 U.S. 497,499 (1954), essentially by incorporating equal protection theory into the Fifth Amendment on the grounds that "discrimination may be so unjustifiable as to be violative of due process."

74. See Califano v. Goldfarb, 430 U.S. 199 (1977) (invalidating Social Security Act scheme of survivor's benefits that provided less protection to female than male employees); Frontiero v. Richardson, 411 U.S. 677 (1973) (invalidating system of air force employment benefits that deprived servicewomen of allowance automatically granted to servicemen).

75. A few opinions have suggested that substantive and procedural due process should have different threshold tests, but none has suggested a reason. See Hampton v. Mow Sun Wong, 426 U.S. 88, 120 (1976) (Rehnquist, J., dissenting) (although alien might have substantive liberty interest "which may not be arbitrarily denied by legislative enactment," he had no "general 'liberty' interest" protected by procedural due process in acquiring or retaining federal employment); see also Block v. Potter, 631 F.2d 233, 236 \& n.2 (3d Cir. 1980) (finding "liberty interest flowing directly from due process clause in not being denied parole for arbitrary or constitutionally impermissible reasons"); Schuemann v. Colorado State Bd. of Adult Parole, 624 F.2d 172, 173, 174 n.2 (10th Cir. 1980) (although Colorado parole statute was permissive, court held parole board decision subject to federal judicial review to determine if decision was "arbitrary, capricious or an abuse of discretion").

76. See supra note 73 .

77. The word "discrimination" in and of itself is meaningless, for all statutes that disadvantage people on the basis of defined classifications "discriminate." In applying equal protection or substantive due process, courts must differentiate between permissible and impermissible classifications. Only classifications that invidiously disadvantage suspect or quasi-suspect groups, impinge on fundamental rights, or disadvantage without a rational basis violate equal protection.

78. 413 U.S. 528 (1973). 
out any rational basis."79 The only liberty right at stake was the right not to be disadvantaged arbitrarily. ${ }^{80}$

On a technical level, substantive due process cases suggest a fundamental liberty right emanating directly from the due process clauses to the equal receipt of governmentally distributed benefits, a right that prohibits distinctions among recipients unless those distinctions rationally further a legitimate government policy. Yet if that right is fundamental, invoking substantive due process scrutiny even without a positive law entitlement, it should also invoke the scrutiny of procedural due process. Just as "arbitrary" or vindictive standards for distributing a benefit violate substantive due process, so should procedures that invite adjudicators to be arbitrary and vindictive. The right not to be disadvantaged arbitrarily is threatened not only by improper legislative classifications but by biased, careless or unstructured adjudcation as well.

On a deeper level, these substantive due process cases point out the proper judicial function in due process cases. At least one motivation for judicial scrutiny of legislative classifications is the potential lack of legislative concern for politically powerless individuals and groups; that potential lack of concern also necessitates scrutiny of adjudicatory procedures. Just as the government may enact classifications that victimize the politically powerless, so may government fail to provide adequate procedures if the interest protected has primary value to the powerless or if those powerless have special needs for procedural protection. ${ }^{\mathbf{8 1}}$

79. Id. at 538. Some evidence suggested that the illegal provision denying food stamps to households of unrelated inhabitants reflected congressional hostility to "hippie communes." Id. at 534. But the Court was clearly concerned less with protecting hippies as a suspect class than with the arbitrary impact of this provision on poor people living together to share costs who would otherwise be eligible for assistance. See id. at 538.

80. In most of the due process/equal protection cases, as in most equal protection cases generally, the courts have struck down race- or sex-based classifications through heightened scrutiny of a suspect category. Some commentators have therefore argued that courts should conceptualize the equal protection right as a right not to be disadvantaged on the basis of defined characteristics, like race or sex. See Westen, The Empty Idea of Equality, 95 HARv. L. Rev. 537 (1982). But the Supreme Court has reiterated in recent cases that the equal protection right includes not just a right against invidious classifications but also a right against arbitrary classifications. See City of Cleburne v. Cleburne Living Center, 105 S. Ct. 3249 (1985); Logan v. Zimmerman Brush Co., 455 U.S. 422 (1982) (opinions of Blackmun, J. \& Powell, J.). As incorporated by the due process clause, the liberty right of equal protection includes the right not to be disadvantaged by the arbitrary denial of a benefit.

81. In criminal adjudications, the political system may provide insufficient procedures because careless procedures and police, prosecutor and jury discretion threaten ethnic minorities or the poor far more than they threaten well-off whites. That prisoners are disproportionately poor and of minority races may then explain why arbitrary parole procedures are politically tolerable. Compare Easterbrook, supra note 67, at 112 (arguing that government will provide optimal level of procedural protection for parole because "even the president of a large corporation . . . is a potential prisoner"). Insufficient procedures in the provision of business or professional licenses may result from undue influence by those who benefit from sloppy procedures. Sloppy procedures may make decisions susceptible to political influence. Alternatively, insufficient procedures may simply reflect an endsoriented approach of a political majority anxious to save resources. So long as enough fishing licenses issue to satisfy public demand for fish, for example, the public might not care how many individual 
This understanding of the courts' role shows the true nature of the entitlement paradox: Although the political process will ensure that interests important to the majority are defined as entitlements, the political process is likely to protect these interests with adequate procedures. The interests not adequately protected are often likely to be those not defined as entitlements. The entitlement analysis does not just present a logical paradox but it substantively restricts constitutional due process protection exactly to where it is not needed. ${ }^{82}$

\section{B. The Entitlement Analysis as a Protection of Reliance}

Another defense of the entitlement analysis suggested by the Supreme Court argues that due process protects only those interests on which government has induced people to rely. ${ }^{83}$ The entitlement analysis provides the proper test, according to this thinking, because government induces a "legitimate" or "justifiable" expectation only if it explicitly promises to provide a benefit (and not to revoke a benefit) upon the satisfaction of specific criteria. $^{84}$

The reliance theory suggests an analogy to a private donor. Like the private donor, the argument suggests, government faces no restrictions in the way it distributes its gifts unless it estops itself. But, as already shown, the entitlement analysis does not just determine how due process applies to the distribution of benefits, it also determines whether an interest is a

fishermen are crushed by capricious decisionmaking. This same political failure can exist even in the distribution of benefits, like public housing, that the government provides largely to aid the recipients. The political majority may care more about raising slums than about assuring that the deserving have an equal opportunity to receive the benefit. But $c f$. id. at 111 (arguing that political power demonstrated by poor people to gain welfare benefits means they have power to protect themselves procedurally).

82. Of course, the exceptions to the entitlement analysis help ensure protection for many important interests. See supra notes 12-14 and accompanying text. But saving a doctrine by not applying it does not defend the doctrine itself.

83. The Supreme Court has hinted occasionally that the entitlement analysis protects not only induced reliance but also actual reliance. See Dumschat, 452 U.S. at 465 (focusing on substantiality of expectation); Roth, 408 U.S. at 577 (right to hearing vindicates claims "upon which people rely in their daily lives"). The contention seems untenable, however, that people's actual reliance depends on the substantive criteria that confine administrative discretion. See Note, Statutory Entitlement and the Concept of Property, 86 YALE L.J. 695, 709-14 (1977) (criticizing idea that entitlements determine actual reliance). The Supreme Court has accordingly held that even a "reasonable expectation" of a benefit does not trigger due process unless a government promise makes the expectation legitimate. Leis v. Flynt, 439 U.S. at 443 (reasonable expectation not enough to create entitlement without " $m u$ tual understanding") (emphasis in original). See also Greenholtz v. Nebraska Penal Inmates, 442 U.S. 1, 12 (1979) (requiring "legitimate- expectation"); Montayne v. Haymes, 427 U.S. 236, 243 (1976) (requiring "justifiable expectation").

84. See Olim v. Wakinekona, 461 U.S. at 238 (an inmate has no liberty right to incarceration in particular State absent statutory entitlement because he "has no justifiable expectation that he will be incarcerated in any particular State"); Dumschat, 452 U.S. at 465 (without written promise, individual's expectation of pardon is only "a unilateral hope"). 
benefit in the first place. ${ }^{85}$ Private donors have no inherent, discretionary authority to determine what property belongs to you and what to them, but the entitlement analysis gives that authority to the government so long as no government rule says it cannot. (If no rule limits governmental discretion, what you might consider your property is only a government benefit.) Thus, the reliance theory must presume not only that government has the general authority to give us things arbitrarily, but also that it has the general authority to distribute what we will and will not have arbitrarily.

The reliance theory suffers several fatal flaws. Even if we assume that government can induce reliance only through rules, rules with mandatory, substantive criteria are not the only rules that induce reliance. Government may induce reliance through unwritten rules that express an implicit bargain, ${ }^{88}$ through detailed, albeit permissive guidelines, ${ }^{87}$ and through procedural protections that indicate a commitment to rational, unbiased decisionmaking. ${ }^{88}$ Yet, the courts' strict entitlement analysis has denied claims to due process in each of these categories.

More importantly, even if government can induce reliance in a common law contract sense only through rules, rules are only one relatively insignificant way in which government may induce reliance. The very existence of a government program may encourage or even force private institutions and individuals to rely on it. A subsidized student loan program, for example, may enable universities to provide services they otherwise could not afford and to demand fees they otherwise could not obtain. The program may enable more people to gain college degrees, making a degree more necessary to compete in the workplace. Finally, even as the program increases the cost and the need for a college degree, it may discourage private scholarship programs. ${ }^{89}$ As a result, an applicant denied student

85. See supra notes 20-21.

86. For example, the government may suggest that if a prisoner behaves properly, he will be paroled or have his sentence commuted. $C$ f. Morrisey v. Brewer, 408 U.S. 471,482 (1972) ("The parolee has relied on at least an implicit promise that parole will be revoked only if he fails to live up to the parole conditions."). But see Jago v. Van Curen, 454 U.S. 14 (1981) (per curiam) (mutual understanding regarding parole cannot trigger liberty interest); Dumschat, 452 U.S. at 465 (rejecting circuit court holding that high statistical probability of release suggested unspoken understanding creating liberty interest in sentence commutation).

87. Detailed, albeit permissive, parole guidelines would appear to induce more legitimate reliance on parole than general, but mandatory criteria. But see Boothe v. Hammock, 605 F.2d 661, 664 \& nn.3-4 (2d Cir. 1979) (no entitlement under New York parole law and regulations despite detailed guidelines which establish presumptive parole date because parole statute lacks mandatory language).

88. These criteria at least suggest that certain criteria, like personal bias, will not cause the denial or revocation of an interest. But see Wakinekona, 461 U.S. at 238 (prison rules mandating different panel to initiate and to adjudicate hearing on disciplinary transfer do not create liberty interest).

89. Professor Stephen Williams argues that due process should apply to welfare benefits because the funds used by the government deplete the resources of private donors. Williams, supra note 68 , at 36-38. Government programs also discourage private initiatives, however, simply by making private programs on the whole less necessary. Thus, even if a government program is too small to cause a 
loans may be incapable of attaining the education or the employment position she might have attained had no student loan program existed at all. The creation of a loan program may force an applicant to rely on its fairness to achieve goals she could accomplish without it.

A third flaw with the reliance theory is its limited conception of the reliance guarantee. The reliance guarantee aims to maximize individual freedom of action. ${ }^{90}$ Accordingly, due process should not just protect people when government has induced them to rely, it should ensure them that they can rely. (Similarly, laws are void-for-vagueness not because they falsely mislead people to rely but because they do not enable people to rely.)

Finally, as the void-for-vagueness doctrine recognizes, due process does not just protect reliance. It also protects people against the inequalities, the invidiousness, the corruption, and the lack of accountability that result from placing unfettered authority in the hands of some bureaucrat. ${ }^{91} \mathrm{Em}-$ powering obscure government officials who are far removed from political accountability with unfettered authority over important benefits allows them to manipulate those who depend on their decisions according to their whim and prejudice.

\section{The Argument that Discretionary Decisions Have a Limited Empha- sis on Factfinding}

A third kind of defense of the courts' due process analysis suggests that broad discretion itself makes decisions inappropriate for due process limitations. Starting with the premise that process has value only to the extent that it minimizes the risk of "error" in the "truthfinding process,"92 some cases have suggested that if decisions depend on "subjective evaluations and on predictions of future behavior" that are not based solely on facts, they are inappropriate for due process procedures. ${ }^{93}$ As one circuit court has reasoned, unless an interest is conditioned on "one or more controvertible facts, a hearing and notice would be pointless."

Even if we assume that erroneous factfinding is the sole concern of due

serious drain on private resources, it may still become a necessity to anyone active in the affected field.

90. See Grayned v. City of Rockford, 408 U.S. 104, 108 (1972).

91. "Law has reached its finest moments when it has freed man from the unlimited discretion of some ruler, some civil or military official, some bureaucrat." Heckler v. Chaney, $105 \mathrm{~S}$. Ct. 1649, 1665 (1985) (Marshall, J., dissenting) (quoting United States v. Wunderlich, 342 U.S. 98, 101 (1951) (Douglas, J., dissenting)).

92. Mathews v. Eldridge, 424 U.S. at 335; see also Greenholtz v. Inmates of the Nebraska Penal and Correctional Complex, 442 U.S. 1, 14-15 \& n.7 (1979) (discussing only errors of fact among "possible risk[s] of error").

93. See supra notes $30-32$ and accompanying text.

94. Davis v. Ball Memorial Hosp. Ass'n, 640 F.2d 30, 41 (7th Cir. 1980). 
process, ${ }^{95}$ this argument is flawed, for discretionary decisions still require facts. As Justice Powell has written about the parole release decision, "unless the parole board makes . . . determinations in some arbitrary or random fashion, their subjective evaluations about future success on parole also must be based on retrospective factual findings." ${ }^{\prime \prime 6}$ In fact, a principal justification for granting adjudicators broad discretion is the need to mold policy to the facts of varying situations. As the Supreme Gourt has now held, due process is necessary to assure that discretionary decisions are based on informed factfinding and to assure individuals an opportunity to invoke the discretion of the decisionmaker. ${ }^{97}$

More significantly, this argument is flawed because due process protects against sources of error that result not from factual error but merely from abuses of discretion. (Indeed, the Supreme Court has held that factfinding error may not be a due process concern at all if it results only from negligence and so does not represent an abuse of government power. ${ }^{98}$ ) Although the typical due process requirements for notice and a hearing may serve primarily to assure accurate factfinding, many traditional due process requirements serve primarily to curb abuses of discretion, including prophylactic rules to prevent vindictiveness and bias, ${ }^{9 \theta}$ appellate review for abuses of discretion, and the presence of the public at trial. Due process protections can also go beyond the traditional focus on notice and hearing and include management techniques ${ }^{100}$ or liability rules (and should include decisionmaking standards). Thus, even where all the facts

95. A number of judicial opinions and scholarly writings have asserted that procedural due process serves important values in addition to the prevention of any kind of error. For the views of two of the best known advocates of "dignitary" values, see J. MAshaw, supra note 2, and Michelman, Formal and Associational Aims in Procedural Due Process, in DUE Process: Nomos XVII 126 (J. Pennock \& J. Champman eds. 1977). For doubts about the extent to which these values are truly non-instrumental and doubts about the ability of courts to incorporate them into a due process analysis, see Redish \& Marshall, supra note 68, 482-91; Simon, Liberty and Property in the Supreme Court; A Defense of Roth and Perry, 21 Calif. L. Rev. 146, 187 (1983) (reviewing literature). For a discussion of whether procedural due process should also be available to protect other constitutional rights, as many have argued, see id. at 190.

96. Greenholtz, 442 U.S. at 20 (Powell, J., concurring).

97. See cases cited supra note 34 .

98. See Daniels v. Williams, 106 S. Ct. 662, 665 (1986); Davidson v. Cannon, 106 S. Ct. 668, 670 (1986).

99. See, e.g., North Carolina v. Pearce, 395 U.S. 711 (1969) (to resentence defendant to more severe punishment after successful appeal, judge must provide statement of reasons justifying sentence on basis of defendant's conduct after original sentencing); Tumey v. Ohio, 273 U.S. 510 (1927) (judge with pecuniary bias must recuse himself). The Supreme Court's holdings that judicial-type hearing requirements are less necessary if government and individual interests are in harmony also reflects a sensitivity to situations that reflect greater or lesser potential for adjudicative abuse. See Greenholtz, 442 U.S. at 13-14; Morrissey, 408 U.S. at 480; c.f. Parham v. J.R., 442 U.S. 584, 602 (1979) (community of interest between children and parents seeking to confine them in mental institutions makes many procedural protections unnecessary).

100. See Mashaw, The Management Side of Due Process: Some Theoretical and Litigation Notes on the Assurance of Accuracy, Fairness, and Timeliness in the Adjudication of Social Welfare Claims, 59 CORNELL L. REv. 772 (1974) (arguing for use of quality control mechanisms). 
are clear and only discretionary judgments remain unsettled, many forms of due process protection are still highly relevant. ${ }^{101}$

\section{Integrating the NeEd for Standards Into Procedural Due Process}

Although broad administrative discretion is dangerous, rigid and excessive rules pose alternative dangers. Too many rules, to quote Judge Wright, may "exchange Lewis Caroll's fantasy for Franz Kafka's nightmare."102 Administrators frequently do not know enough to promulgate precise rules, ${ }^{103}$ and the rules they do promulgate, if too rigid, may produce poor results. A benefit of making policy through adjudication is that it permits those affected to participate in forming the rules that deter-

101. Professor Peter Simon advances another reason to exempt discretionary decisions from due process review. See Simon, supra note 95 . He argues that procedural review of discretionary decisions inevitably leads to substantive review to make the procedures meaningful. In turn, that substantive review alters the bases of administrative decisionmaking against the legislative will-discouraging intuition and entrenching the status quo-as administrators seek to make only those decisions that they can defend in court. In contrast, argues Simon, review of non-discretionary decisions alters substantive, legislative purposes much less.

The first response to this argument is that procedural protections need not lead inexorably to substantive review. The purpose of procedural protection is to institutionalize a method of decisionmaking that will produce rational decisions without substantive judicial review. Courts must resist the temptation to engage in routine, substantive review, for procedures assure only probability of regularity, not regularity itself.

The second response to Simon is that intuition differs from discretion. Decisionmakers can use intuitive factfinding regardless of whether they implement specific standards or follow careful procedures. Thus, there is no particular reason to believe that legislatures grant administrators broad discretion to encourage them to use their intuition; legislatures may simply wish administrative decisionmakers to develop their own standards either through rules or through adjudication. Procedural scrutiny of discretionary decisions threatens no more of an interference with legislative will than procedural scrutiny of nondiscretionary decisions.

Professor Simon also supports the exemption for discretionary decisions on the grounds that the traditional nonreviewability of many kinds of discretionary decisions (e.g., prosecutorial discretion, jury findings, executive clemency) indicate that not all government decisions need be rational. Id. at $161-69,191$. But the primary justifications for these areas of nonreviewability (whether or not they are sufficient) are the special government interests in not being encumbered by procedures, not the satisfaction of arbitrary action. See, e.g., Heckler v. Chaney, 105 S. Ct. 1649, 1656 (1985) (primary justifications for nonreviewability of enforcement decisions are special expertise over use of enforcement resources, special difficulty of judicial review, and, to some extent, constitutional commitment to executive branch). In other words, we justify nonreviewability only after applying a due process analysis, not before.

102. Wright, Beyond Discretionary Justice (Book Review), 81 YALE L.J. 575, 576 (1972).

103. Professor Kenneth Davis argues persuasively, however, that ignorance need not prevent rulemaking. See DAvis, Discretionary Justice: A Preliminary InQuIRY 59-64 (1969). Administrators can make rules not only in the traditional form of binding statements but also in the form of standards and criteria or even in the form of examples. In this way, administrators can set out their basic approach to problems without having to determine in advance how they will respond to unusual fact patterns. For a good example of this type of rulemaking, see UNITED STATES DEPT. OF JUSTICE, ANTITRUST DIVISION, ANTITRUST GUIDE FOR INTERNATIONAL OPERATIONS (1977), reprinted in ANtitrust and Trade. Reg. Rep. (BNA) No. 799, at E-1 (Feb. 1, 1977). 
mine their interests. ${ }^{104}$ Accordingly, determining the optimal precision of administrative rules may be difficult.

Focusing on the the need for standards does not force courts fully to confront this difficulty. Although the optimal precision of administrative rules is hard to determine, determining the optimal mix of procedural protections that are the focus of traditional due process scrutiny is equally difficult. ${ }^{108}$ Courts avoid this difficulty in part by setting only minimum standards. ${ }^{106}$ Agencies rarely have an excuse for promulgating no "ascertainable standards."

A second way of dealing with the difficulties of fine-tuning is to leave the actual mix of procedural protections to the agencies. If an agency professes good reasons for leaving broad, even unfettered discretion in the hands of individual adjudicators, a court does not have to judge the merits of its assertions. Courts can respond only by insisting that the agency compensate for the dangers of this approach with alternative procedures. ${ }^{108}$ One important trade-off might involve statements of reasons: the more general the standards adjudicators use, the greater the need for comprehensive explanations of their final decisions. ${ }^{109}$ Courts might also insist

104. In fact, the very use of agency rulemaking to make policy has been challenged, albeit unsuccessfully, as an improper denial of a party's right to a full hearing at the time the rules are applied. See, e.g., United States v. Storer Broadcasting Co., 351 U.S. 192 (1956). For an argument that this participation should be constitutionally required if important privacy rights are at stake, and an interpretation of the Supreme Court's short-lived irrebutable presumption cases in this light, see Tribe, supra note 68 .

105. Scholars have begun to identify the factors that determine the merits in particular cases of having tight or loose rules. See Diver, The Optimal Precision of Administrative Rules, 93 YALE L.J. 65 (1983). Diver identifies three principal tradeoffs: transparency, the clarity of rules based on the use of words with well-defined and universally accepted meanings; accessibility, the casy comprehension of the rule in concrete situations by its intended audience; and congruence, the communication of a substantive content that actually produces the correct results. Id. at $67,71-72$.

Loose rules that leave broad discretion to individual adjudicators are not the only ways of ensuring flexibility, however. Agencies may also have tight rules that create strong presumptions, yet combine them with a developed process for permitting exceptions. See generally Aman, Administrative Equity: An Analysis of Exceptions to Administrative Rules, 1982 DUKE L.J. 277 (reviewing court cases and statutes and attempting to form system of equitable rules for permitting exceptions). Under the aegis of federal administrative law, federal courts have encouraged agencies to use an exceptions process. See, e.g., WAIT Radio v. FCC, 418 F.2d 1153 (1969) (insisting on meaningful response to request for waiver of agency rules).

106. The Fifth Circuit, for example, following its holding in Hornsby v. Allen, 326 F.2d 605 (5th Cir. 1964), that a complete lack of standards for liquor licensing violated due process, proved willing to tolerate an ordinance that lacked "much in the way of precision." Atlanta Bowling Center, Inc. v. Allen, 389 F.2d 713, 716 (5th Cir. 1968).

107. In Hornsby, the Fifth Circuit ordered the liquor licensing board to establish "ascertainable standards by which an applicant can intelligentsly seek to qualify for a license." 326 F.2d at 612 .

108. Judge Friendly has suggested, "[i]f an agency chooses to go further than is constitutionally demanded with respect to one item [of a hearingl, this may afford good reason for diminishing or even climinating another." Friendly, supra note 28, at 1279; accord Buss, supra note 6, at 639 (endorsing this approach for applying due process to school setting). The Supreme Court appears to have accepted this idea. See Pulley v. Harris, 465 U.S. 37, 51 (1984) (implying that one form of procedural protection in death penalty context-viz., proportionality review-could compensate for other checks).

109. Courts have taken this approach to protect against abuses of administrative discretion in 
that agencies compensate for broad discretion with an open system of precedent that forces the development of more precise standards over time, ${ }^{110}$ or with a system of meaningful internal administrative review with independent adjudicators. If the justification for broad, case-by-case discretion lies in the importance of molding policy to the particulars of individual situations, adjudicators need the participation of those affected to understand those particulars fully. ${ }^{111}$ Finally, courts should consider management control techniques and liability rules. These protections may diminish the potential for the abuse of government power without inflicting unnecessary bureaucratization on administrative activity.

Eradicating the entitlement analysis does not imply rejecting the use of some threshold test for invoking due process. The availability of due process litigation offers those dissatisfied with government decisions the capability of applying enormous pressure on their behalf. If cases cannot be dismissed at the pleadings stage, dissatisfied parties may unfairly harass and inflict high legal costs on a wide range of government operations that

applying federal administrative law. See Dunlop v. Bachowski, 421 U.S. 560, 572 (1975) (agency must "delineate and make explicit the basis upon which discretionary action is taken" and reason should "cover the relevant points and eschew irrelevancies") (citation omitted); Environmental Defense Fund v. Ruckelshaus, 439 F.2d 584, 596-98 (D.C. Gir. 1971) (suggesting that agency "articulate... standards and principles" to govern discretion but ordering, if agency alternatively chooses to develop standards case-by-case, that it "articulate the criteria that [it] develops in making each individual decision"). Courts have also obligated agencies to explain explicitly any departure from prior norms. See, e.g., Secretary of Agriculture v. United States, 347 U.S. 645, 653 (1954) (reversing administrative decision because "Commission has not adequately explained its departure from prior norms"); Greater Boston Television Corp. v. FCC, 444 F.2d 841, 852 (D.C. Cir. 1970) ("IA]n agency changing its course must supply a reasoned analysis indicating that prior rules and standards are being deliberately changed, not casually ignored."), cert. denied, 403 U.S. 923 (1971).

110. In SEC v. Chenery Corp., 332 U.S. 194 (1947), the Supreme Court upheld the use of adjudication to make policy because of the problems presented by agency inexperience and by the adjudication of unforeseeable, specialized, or varying matters. These problems justified "the case-bycase evolution of statutory standards." Id. at 203. The Court did not, however, uphold a continuous use of ad hoc decisionmaking without any attempt to evolve standards. Unless adjudicators make some attempt to build policy out of individual adjudications, the Chenery justification for ad hoc discretion collapses.

111. Applying this approach to Greenholtz v. Inmates of the Nebraska Penal and Correctional Complex, 442 U.S. 1 (1979), suggests that the very discretionary and intuitive nature of the parole decision should increase the obligations for other protections. Parole discretion increases the likelihood that decisions will be unequal, that parole boards will penalize conduct that society as a whole considers acceptable and that decisions will be motivated by personal vindictiveness. Furthermore, if parole boards are to use subtle, subjective evaluations of inmates in making decisions, they should at least seek to give some structure to their intuitions through a statement of evidence. Indeed, a subjective decision is all the more influenceable by erroneous hearsay, so access to a parole file would appear essential. In contrast, a parole decision based on objective factors, like the federal parole system, see 28 C.F.R. \& 2.20 (1984), gives a prisoner relatively easy notice of the evidence a parole board has used and reduces the potential mischieviousness of false innuendo.

Similarly, in Board of Curators of the Univ. of Mo. v. Horowitz, 435 U.S. 78 (1978), the very fact that dismissal did not follow automatically from poor academic performance but from a discretionary decision demonstrates the importance of some kind of "informal give and take." In contrast, a nondiscretionary rule would present little reason for any kind of hearing but only an opportunity for challenging the factual accuracy of the academic record. 
distort their decisionmaking. Granting process rights to everyone, furthermore, may crowd out the process rights of those with most at stake.

Instead of relying on the existence of discretion, however, the availability of due process should depend on more appropriate criteria. The courts can accept a de minimis exemption from the requirements of due process if the individual interest is minor, ${ }^{112}$ or a "de maximis" exception if the government interest is overwhelming. Finally, some kind of standing requirement might deny due process rights to some parties if a limitation is necessary to protect the impact of the due process rights of those with most at stake. ${ }^{113}$

\section{CoNCLUSION}

At root, support for the entitlement analysis may rest on reluctance to impose growing procedural burdens and continuing lawsuits on government agencies. The value of administrative process is virtually impossible to measure while the bureaucratization and legal expenses it forces on government agencies are highly visible. The entitlement analysis permits agencies to escape due process by writing their rules in particular ways. But if agency emancipation is our aim, the entitlement analysis does not accomplish it. Many administrators continue to prescribe mandatory standards that bring decisions under due process scrutiny despite the disincentive of the entitlement analysis. Even those who are hostile to judicial demands for process have no reason to burden those administrators in particular or to encourage them to abandon their standards.

Other factors remaining equal, substantive standards reduce the threat of government abuse. A lack of standards increases the need for other forms of procedural protection. By exempting some decisions under sensible threshold criteria, by permitting adjudicators to choose their own mixture of procedural protections, and by concentrating not only on hearing

112. The Supreme Court accepted the de minimis principle in Goss v. Lopez, 419 U.S. 565, 576 (1975); see also Rose v. Nashua Bd. of Ed., 679 F.2d 279, 282 (1st Cir. 1982) (short suspension from school bus service is de minimis); Pegram v. Nelson, 469 F. Supp. 1134, 1140 \& n.12 (M.D.N.C. 1979) (four months suspension from public school extra-curricular activities is de minimis).

113. Thus, a potential government contractor should probably not have a due process right to a fair bidding opportunity on every government contract. See Coyne-Delayny Co. v. Capital Dev. Co, 616 F.2d 341 (7th Cir. 1980) (no general due process rights to hearing before government purchasing decision); of. Hill Aircraft \& Leasing Corp. v. Fulton County, 561 F. Supp. 667, 678 (N.D. Ga. 1982) (would-be lessor of aircraft facility has no due process right to competitive bidding on lease), aff'd mem., 729 F.2d 1467 (11th Cir. 1984). On the other hand, government contractors invited to bid should probably have due process rights to a fair consideration of their bid. But see Polyvend, Inc. v. Puckonis, 77 IIl. 2d 287, 32 Ill. Dec. 872, 395 N.E.2d 1367 (1979) (denying any such rights). Contractors should also have due process rights before government excludes them from all contracting. See Art Metal-USA, Inc. v. Solomon, 473 F. Supp. 1, 4 (D.D.C. 1978) (before government contractor may be blacklisted from future contracts, due process requires notice and hearing of charges against 
procedures but also on management and liability protections against adjudicative abuse, courts can protect against the dangers of discretion without increasing their intrusiveness into administrative management. 